\title{
Portrayal of Women and their Mental Trauma in the Patriarchal Society through the Play 'Kamala' by Vijay Dhondopant Tendulkar
}

\author{
L.Priyadharshini
}

MA English Literature, Department of English and Foreign Languages, Bharathiar University, Coimbatore, Tamilnadu, India

Received: 14 Nov 2020; Received in revised form: 03 Dec 2020; Accepted: 08 Dec 2020; Available online: 19 Dec 2020

(C)2020 The Author(s). Published by Infogain Publication. This is an open access article under the CC BY license

(https://creativecommons.org/licenses/by/4.0/).

\begin{abstract}
Women, the ones to whom equal importance should be given to men in this world are always portrayed as weaker sex throughout centuries. In the play 'KAMALA' (1981), the playwright picturises the status and the position of women and how they were treated and viewed by the male community as a pawn to attain their aim and desires. In this play, the characters 'Kamala' and 'Saritha' have continuously been treated as slaves by the society and by her husband who was a journalist 'Jaisingh' respectively. The physical and mental traumas which the characters undergo throughout the play represent the pain and the sufferings of the whole female community in male-dominated society. The society itself creates such an ideology to see women only as a body which provides sexual pleasures and not as a human with emotions and feelings. The research paper vividly examines how women were socially tuned by society as a commodity and the conflict between master and slave.
\end{abstract}

Keywords- Women as weaker sex and commodity, patriarchal society, the mental trauma of women.

\section{INTRODUCTION}

Vijay Dhondopant Tendulkar was an Indian playwright, journalist, and essayist. He was born in Mumbai, Maharashtra and he was a Marathi writer. He was very much influenced by the political upheaval of the society and all his works were based on the real life incidents that prevailed in his contemporary society. Society and political issues were thrown under the light as such in his plays. Women characters were given more importance in his plays. In all his plays women were portrayed only as a tool for sexual pleasures of men and as slaves which was the reality during his period. In the play 'KAMALA', the character Kamala has been forced by her society to become one of the women who were sold in auction to the male community who choose them under different parameters such as age and health issues. Saritha, though she holds the title 'wife', she was treated as a subaltern woman of slaves by her husband in the family. Patriarchal societies attain their desire and reputation by suppressing women.

\section{WOMEN- AS A COMMODITY}

Women are considered only as mere objects without any life or emotions. When Jaisingh brings Kamala to his house, Saritha was shocked to hear that she was bought. The word 'BOUGHT' goes with something that does not hold much importance other than a living entity. The conversation between Jaisingh and Saritha clearly explains the state of women as an object in society.

JAISINGH: I bought her--- in the Luhardaga bazaar in Bihar.

SARITHA: Huh? [She can't understand]. Bought her?

JAISINGH: Yes. For two hundred and fifty rupees. Even a bullock costs more than that.

[Saritha is stunned]

[Brightening as he notices her reaction.] They sell human beings at this bazaar at Luhardaga beyond Ranchi. Human beings. They have an open auction for women of all sorts of ages. People come from long distances to make their bids.

SARITHA: They auction--- women? 
JAISINGH: Yes, women. Can't believe it, can you? The men who want to bid ---handle the women to inspect them. Whether they are firm or flabby. Young or old. Healthy or diseased. How they feel in breast, in their waist, in their thighs and.....

\section{SARITHA: Enough.}

So, it is evident that women are valued by their feelings or emotions of inner self but only by their physical appearance of skin, colour, age, and health. The society is tuned by a very firm and strong ideology that women are only a sex toy that dances to the tunes of male. Jaisingh informs Saritha that, since Kamala had no customers, he has bought her for cheap to be used as evidence before the press conference for his job. As a woman, Saritha could not digest the state of women hood in society on seeing the plight of Kamala. Even women, like Kamala, had no awareness of their position and they do accept all the words of their masters because of the forces of the powerfully structured society.

Saritha, another most important character in the play is the representation of middle-class women in society. From the beginning of the play, she has been shown only as a slave to her husband who does every work for him without raising any questions against him. This shows how women were dominated by men and also on the other hand the respects that were shown by wives to their husbands. Saritha was caught in the circle of family bond called 'marriage' which made her slave by her husband. The mental trauma which she faces has no words to explain. The relationship between husband and wife was replaced by the relationship between master and slave.

KAKASAHEB: .........Kamala is just a pawn in his game of chess.

SARITHA : Not just Kamala, Kakashaheb. [Trying to control her misery.]

Not just Kamala, Kakashakeb. Me too ... me too.

These words of rage and anger explain the outbursts of her feelings and opinions about her position in her family. The self- realization made her overcome all the taboos that were knit around her.

\section{PATRIARCHAL ELEMENTS - POWER} AND SLAVE

Sub-alternity prevails everywhere in the society which cannot be easily ignored. The term patriarchy means the government or society that is controlled by men. In this play, the term patriarchy can be directly related to Jaisingh. All the three women in the play, her wife Saritha, the women he bought Kamala, and his house servant Kamalabai in one way or the other has been manipulated by the so called power which he has that is he belongs to the gender 'MAN'.

Jaisingh, one of the most reputed journalists in his society was a man of dominance and cruel- hearted man who never respect anyone who is against his ideas and thoughts. He never shares or informs his wife about what was he doing or where he was going. Saritha as she was a woman never asks him anything.

JAISINGH: Come upstairs.

SARITHA: [Emphatically, without even realizing it]. No.

JAISINGH: I'll have my dinner afterwards. We'll both eat together.

SARITHA: [Without losing her self-control]. Uh-hunh, let me go. I've got work to do.

JAISINGH: [Trying to embrace her]. Work later. Come upstairs now.

SARITA: [Throwing him aside with a single shove]. Move aside. What are doing?

JAISINGH [Hurt]: What's the matter? What did I do? Why are you making a face like that? Why did you push me away? You've never done that before.

[Sarita is in the grip of heartfelt aversion. She is in no state no reply]

JAISINGH: Tell me, come on. I'm your husband, after all. What was wrong about what I said?

[Sarita is trying to control her aversion]

JAISINGH: You must tell me. I must know. Don't have the right to have my wife when I feel like it? Don't I? I'm hungry for that too-I've been hungry for six days. Is it a crime to ask for it? Answer me!

[Exit Sarita towards the kitchen].

Through this conversation, the way how Jaisingh treats his wife is clear. He shows his dominating power as her husband to have sex with him whenever he desires to have. Women in his eyes are only to fulfil the sexual thirst of men.

The only motive of Jaisingh is to achieve high popularity and fame in society through his job as a journalist. So he bought Kamala, for two hundred and fifty rupees. As a citizen and as a human being he doesn't have any motive to rescue her and get her justice. Rather, he used her only as evidence for his press conference.

JAISING: I just wanted her to present as evidence. And that was done. 
The stereotype is that as a man, they think that they have every right towards women. The questions which were thrown towards Kamala in the press conference seem very horrible and ruthless. As women, no one should come across those questions in their life. Words have much power to make a person happy and put one down.

Kakasaheb consoles Saritha by forcibly proving the nature of manhood. Through this, the mentality of manhood is clear that dominating and making women dance to their tune is their right.

\section{CONCLUSION}

Human values are exploited selfishly by another human being. The exploitation of women hood by the male chauvinistic society has been picturised through the characters in the play. The era when the play was written is not only the time that witnessed inequality and patriarchy but it prevails even in this era in several places. The physical sufferings can be easily seen through the eyes but the mental and inner self- trauma cannot be seen visibly. Women are seen as a commodity under the trade masters of manhood. Time has to come when women should raise their voice against the suppression which they face by the male society. Patriarchy never fades until the minds of every individual man change their attitude towards women and their feelings.

\section{REFERENCES}

[1] Kamala - Vijay Tendulkar.

[2] Tendulkar, Vijay. 1995. Five Plays. Delhi: Oxford University Press.

[3] Dhibar, Shovan. "Vijay Tendulkar's KAMALA : A Pathetic Picture of Women in Indian Society." The Contour 1.1 (2014): 36-42. Print. 